\title{
The Impact of Service Recovery on Repurchase Intentions: A Moderated Mediation Model
}

\author{
Muhammad Salman Latif \\ School of Business Administration, Northeastern University, Shenyang, China \\ salmanlatif98@gmail.com \\ Zhang Lanxia., PhD \\ School of Business Administration, Northeastern University, Shenyang, China \\ Ixzhang@mail.neu.edu.cn
}

\begin{abstract}
The purpose of this paper is to fill an important gap in literature by exploring the moderating role of customer emotions and the mediation of perceived fairness on service recovery effecting repurchase intentions. Based on the data of 200 valid questionnaires collected from oversees Pakistani in China, this paper used SPSS v.21.0 for data processing and analysis in which the reliability test was conducted and the hypothesis testing of direct and indirect effect was done on SPSS extension called Process v.2.3 developed by Hayes (2013). Results reveal that all variables of the study significantly correlate with each other, the service recovery has a significant impact on repurchase intentions. Results also disclose that perceived fairness mediates the effect of service recovery on repurchase intentions while moderation of customer emotions supporting the existence of moderated mediation. The findings of this study are particularly valuable for managers, it allows them to enhance the understanding on the aspect of service recovery that leads to repurchase and will help management to make an effective retention/repurchase strategies in service recovery situations.
\end{abstract}

Keywords: service recovery, repurchase intentions, customer emotions, perceived fairness

\section{Introduction}

Repurchase is widely consider to be the most important factor for the profitable business in a history, however many business firms and entrepreneurs are still not convinced of the value of customer repurchase and pour much of their resources on establishing strategies that will bring in new customer rather than bringing them back to purchase again. Kotler (2003), highlighted the importance of repurchases in his book that cost of retaining old customer is lower than the cost in the development of relationship with fresh customers.

In addition, increasing repurchase intentions of the customer is highly beneficial for companies in terms of cost incurred and profitability. A study of Reichheld and Sasser (1990), on repurchase intentions also pointed the solid

The current issue and full text archive of this journal is available at http://jraspublications.org/index.php/JRAS/issue/archive Journal of Research in Administrative Sciences (JRAS)

VIII(I), 10-25, ISSN: 2664-2433 argument that companies' profits will increases if there is a decrease in the turnover rate of customers.

The motivation for this study derived from the fact that repurchase intentions is highly important for the firm profitability and its market performance especially in highly competitive market, following are the key reasons, why repurchase intention of customer is significant: (1) It is cheaper to get old customer to purchase again, because putting some marketing efforts with the focus on existing customers will leads a higher returns on companies investments on marketing. (2) Existing customer will help organizations to promote business because these are happy customers and they will spread word of mouth so quickly. 
(3) Repeat customer increases transactions in business that will increase companies' profits because of buying more than once and spending more compared to those customers who only bought once. (4) It helps in expansion of business, according to marketing pioneered Kotler (2003), a great way to grow any business is to finding more products or offering more services that can be sold to the same customers.

Marketing mangers relay on repurchase intentions to forecast sales in a number of activities in marketing such as introduction of new products, advertising effectiveness, service management and forecasting demand for their existing products, subsequently, in academia, researcher frequently used repurchase intentions as proxy for customer purchase behavior ${ }^{[3]}$.

Services represent a high percentage of global economy, and in recent times, manufacturing based economy shifted towards services. The understanding of this change in services marketing and services research is necessary for the firms in order to remains in competition especially at national level ${ }^{[15]}$. The current study also focused on repurchase intentions of customers in service sector in recovery situations, the reason because service recovery covering the whole world like a storm, if companies can deliver effective customer service and exceptional recovery of service after a failure, their customers will feel valued, and hold a greater emotional connection to firm that decided fairness received which ultimately leads to repurchase from the company. Repurchase intention as a result of emotional response is a grave concerns for the companies as it affecting future relationship, profitability of company, and therefore the success of business.

A considerable attention has been paid in prior studies on failure of service and its recovery in service quality satisfaction but there still a lack of focus/attention on research in service recovery with repurchase intentions. Repeated customer's means greater sales and greater customer repurchase, both of which pay dividends for both reputation and income. So it is important to examine and fully understand repurchase intentions of customer towards services. Nonetheless previous academic studies examines variability in behavior intentions though the scope has been limited, there is needed an in-depth study to widen the scope and the present research has focused on repurchase intention in growing service industry.

An important aspect in repurchase during service recovery situation is perceived fairness and according to the theory of justice, the rapid response from service provider in recovery decreases negative spreading's and positively increases customer repatronage intentions, justice theory consider perceived fairness as mediation because when decision relating to rectification of service recovery is made, customer make judgments about the outcome whether it is fair or not. Therefore this study take perceived fairness as a mediator in which different dimension of justice/fairness determine the effect between recovery and intentions.

Customer emotions are highly important function for companies to maintain customer repurchase, according to theory of Affect Control (ACT) emotion with highly positive or negative valence have a significant moderating role in process of service recovery which may breakup rebuying parameters. This study also consider customer emotions as a moderator because when customers experiencing inadequate recovery of it service, they will express their feelings and act in a way which permits them to recover their own identity and when recovery of service achieves a positive results, customer consider the treatment as fair and likely to remain loyal with company resulting repurchase, however negative emotions perceived as unfair resulting disloyalty and un-subscription from service.

\section{General Objective}

The general objective of research was to examine the impact of service recovery on repurchase intention.

\section{Specific Objectives}

1) Analyze the impact of service recovery on perceived fairness.

2) Identify the impact of perceived fairness on repurchase intention.

3) Analyze the mediating effect of perceived fairness on service recovery and repurchase intention

4) Analyze the moderating effect of customer emotions on service recovery and perceived fairness

5) And lastly analyze how emotions moderate the mediation role of perceived fairness between service recovery and repurchase intentions.

The model of this study is important because its bridges the gap in literature as prior literature did not emphasis on impact of on repurchase intention with mediation of 
perceived fairness also a moderation of customer emotion. This research not only enriches the theoretical research of customer repurchases intentions in theory, but also provides operational guidance for how to improve customer repeat purchase and helps organization to make an effective strategies for increasing repurchase and sales.

\section{Literature Review}

\section{Repurchase Intentions}

Zeithaml and Berry et al. (1996) defined it as a decision of customers to buy product/service in future after fully concern with their current situation and other related circumstances. On the other hand it defines as customer persistent intention to buy from the company/firm. Lacey and Morgan (2008) described his view about repurchase intention relates to the person decision for purchasing from the same company or firm repeatedly.

Some preliminary work in early 1990s was carried out on repurchase intentions which highlighted the importance of repeat purchasing from the current customer because the cost of reaching to new customer much higher than the cost to retain customer [7]. Another study indicated that intentions of customer can guide them to repurchase ${ }^{[8]}$. Recent research by Bao (2017) in which he argued that no matters whether it's a traditional industry of product/service, the e-commercial, are all highly attached to repurchase behavior of customer.

According to Lapierre (2000) considered repurchase intention as a subjective possibility of customers to purchase commodity however a study of Oliver (1993) strongly believed that when the demand of particular product or service increased, the customer attitude towards choice of selecting service provider remains identical. Luo and $\mathrm{Yu}$ (2017) has been identified in service recovery, if the relationship between user and service provider is quality oriented then the customers may keep a higher intentions to repurchase because they trusts the service provider but they also may become disappointed with the final outcome due to having a higher expectations form the provider. Therefore a study based on social exchange theory explains that repurchase intentions reflects the client's willingness to maintain relationships with the company, providing the service.

Much work on the potential of strategic measure has been done on how to take corrective measures in order to maintain the cost associated with those measure and increase repurchases. However, there is still need to demonstrate further relationship logically with regards to the service recovery and repurchase intention. If service recovery can be fairly treated, which recompense the loss of effected customer or exceeds expectations of them, will impact positively on repurchase intents. On the contrary of this, companies who fails in the recovery will make unhappy buyers angrier, they will show no interest for repurchase ${ }^{[15]}$.

\section{Service Recovery}

The term service recovery was previously defined by many authors in different perspective; for instance Johnston (1995) defined it as "seeking solution to failure of service", whereas Bell and Zemke (2013) describes as "a planned procedure of returning angry customer in to a state of gratification with the company, offering particular services. Furthermore, recent research rendered a definition that the service recovery is an ultimate response form the company to the failure of service ${ }^{[24]}$.

According to Grönroos (2003) service recovery includes a set of several actions conducted by services firms to compensate the losses incurred during failure. These actions includes various forms of compensation this can be economic resources for example (reimbursements, discounted prices, offering free products or services, service up gradation) or can be social resources for instance apologies to customer, acknowledgement of the problem, intervention in management ${ }^{[26,27]}$.

With reference to the above mentioned studies the performance of recovery examined as a reaction to the situation in this research, through which the complaint of customer originates the recovery actions ${ }^{[27]}$. This research is different from the prior studies done by Wanger, Smith and Bolton, who surveyed a random sample on airline customers about failure of service they had encountered, whereas all these three authors developed a set of different scenarios for hotels and restaurants customers to capture responses. In addition their research includes a model of mental reasoning which involves principle of exchanges of economics resources for service recovery. This research, as

first of its kind that conducted in Pakistan to take further 
explanatory approaches and seeks to quantify the relationship between SR and RI.

An extensive review indicated that the apology, speed, compensation, facilitation effort and solving of problem are an effective responses from organization after service failure ${ }^{[16,27,30,31]}$. When customer faces failure they expect service firms to be accountable for it, want a rapid response, compensation for any inconvenience and fair treatment during the process handling complaints. Apologizing and amending problem are the strategies that most of the companies use widely in recovery process ${ }^{[32]}$. The current study adapted three dimension of service recovery from study of Yang and Peng (2007) that have influence repurchase, these includes, compensation, speed, and apology.

\section{Service Recovery and Repurchase Intentions}

Service recovery refers to the organization remedial actions after failure. When failure occur, service provider need to counter it effectively in order to reduce the fear of customer loss caused by ineffective treatment. A study of Gilly [36] mentioned that companies who perform well during recovery process will have higher rate of repurchases. An effective response to the failure of service not only upsurge satisfaction but also prevent consumer behavior of switching brand. A study of Spreng, Harrell ${ }^{[8]}$ reveals that service recovery positively correlated with repurchase intentions.

Several studies identified different actions that an organization may use for SR such as

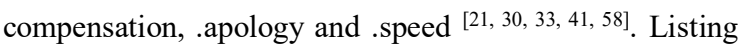
these actions is useful for service provider and a detailed review of literature highlighted that these three dimensions are an effective responses from service firms ${ }^{[21,30,33]}$. An apology by firms shows a sense of responsibility for any inconvenience that customer face (Boshoff, 1999), while speed in response to customer complaint increase satisfaction and rebuying intentions, similarly compensation in different forms such as discounts, refunds and coupons, enhances repurchase intentions ${ }^{[35,37]}$.

As extensive literature review identifies better service recovery by the service firm can positively impact customer retention and repurchases intentions, therefore, current study assumes following hypothesis:

$\mathrm{H} 1$ : Service recovery has significant positive effect on repurchase intention

\section{Mediation of Perceived Fairness}

The concept of fairness deals with justice, or the perception that an individual make with reference to what type of service quality they received form firms ${ }^{[44]}$. Studies have shown that perceived fairness in relation to service recovery and repurchase intentions often relate with each other. A study of McColl-Kennedy and Smith, wrote about theory of justice, which based on the view that satisfaction and future buying intentions of customers depends on their feelings of whether they are fairly treated and that justice was done or not ${ }^{[74]}$.

Broadly speaking, theory of justice states that customer feeling satisfied, when his input in process the exchange during delivery of service balanced perceived output. Likewise, if customer treated equitable then this refereeing to distributive justice ${ }^{[18]}$. In addition, customer decide perceived fairness of the outcome during recovery process known as procedural justice $[72,73]$. The aspect of interpersonal interaction in which stress to process of service recovery carried out and delivery of information done by firms to customer is referred to as interactional justice ${ }^{[27,47,74]}$

To better perceive the mediating role of fairness, researcher tried to develop the relationship among three dimensions of fairness/justice, satisfaction and customer behavioral intentions ${ }^{[33]}$. According to justice theory, fairness and its dimensions constitute a mediate stage in the process of rendering effort regarding to service recovery which strongly influence customer perception of the ultimate outcome such as repurchase intentions, based on above, following hypotheses proposed

H2: Perceived Fairness mediate the relationship between Service Recovery and Repurchase intentions

\section{Moderation of Customer Emotions}

Customer emotions play a vital role in service recovery circumstances for its two key reasons [55]. Firstly, an increasing trend for the analyzing or evaluating the main outcome of SR called satisfaction that has both the cognitive and emotional antecedents ${ }^{[18,56,57]}$. Secondly, it has been claimed in the literature that a number of customers, during recovery encounters, feel stronger emotional reactions which particularly influence the 
decision of customer intentions on whether to endure a relationship with firm in term of repurchase ${ }^{[58]}$.

As a mentality of readiness for actions, emotions arise from an individual when he or she evaluate the importance of event ${ }^{[59,55]}$. Therefore, emotions impact on the behavior of customer in a state of readiness for action ${ }^{[60]}$. In addition, it also contributes to an individual's guiding on thinking and decision making plus an action [61] [62]. In marketing perspectives, emotions consider as a crucial factor that affect customer's behaviors and their purchasing decisions ${ }^{[64]}$. In service recovery context, emotions are expected to be triggered before the customer behavior and repurchase intentions.

According to Izard (1997), three sets of emotions identified which includes positive such as happiness, pleasure and joy and negative includes anger, offense and disappointment and also the combination of both the positive and negative emotions. Recent research described context-specific emotions in a company for example call centers where customer normally wants to gain a goal relates to utilitarian focused such as problem solving in their service or managing their accounts ${ }^{[65]}$. This study will focus more on customer emotions and analyze the moderating effect of them after recovery process that leads to repurchase.

Using the Theory of Affect Control (ACT), past study of Chebat and Slusarczyk emphasizes that the level of perceived fairness depends upon the emotions that customer experienced during service recovery. The result of his study manipulate that high level of negative emotions correspond to low level of perceived fairness. He further argued that not many studies determines the reactions of emotional influence to fairness and those who did are mostly experimental designs, measured a reaction due to manipulated situation ${ }^{[73]}$.

According to Affect control theory (ACT), customer emotions consider an important function for service provider. Sentiments that have high positive or negative valence such as anger/ excitement show the outcome of service recovery and decides the fairness parameters. For instance, during service recovery, if he face inadequate response he become unhappy or disappointment and if he feels the recovery from provider is suitable, he felt pleasant and happier, these emotions decides the fairness of treatment provided by the firm, therefore based on above theory, this study assumes the hypothesis as follows

H3: Customer emotions can moderate the relationship between service recovery and perceived fairness.

H3a: When customers have positive emotions, the relationship between service recovery and perceived fairness is high

$\mathrm{H} 3 \mathrm{~b}$ : When customers have negative emotions, the relationship between service recovery and perceived fairness is low.

ACT theory further describes that customer sentiments also influence loyalty and repurchase of company. These emotions during recovery process estimate the fairness level which then leads to repurchases of services. In applying fairness to recovery event, customer can imagine a number of sequenced actions, when a service recovery attains a positive result, the customer will like to remain more loyal to the company, however negative emotions arise from the service recovery felt them to be unfairly treated resulting disloyalty of customer or may unsubscribed from the service, interactions among people involve responses with emotions and feelings which will influence whether relationships are maintained [81]. Therefore we put forward another hypothesis:

H4: Customer emotions can moderate the relationship between service recovery and perceived fairness through fairness only, the mediation effect of fairness between service recovery and repurchase intention is stronger under condition of positive emotions.

The literature review above has facilitated us in the development of conceptual framework for current study in the figure 1.1 below:

Fig. 1.1 The research model of this paper

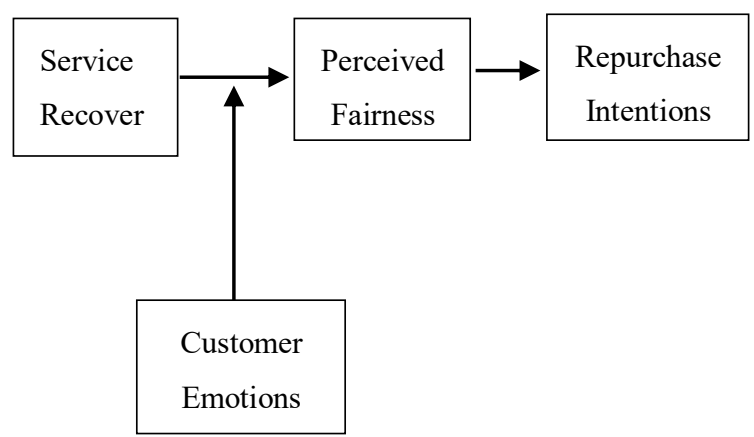

\section{Methodology \\ Data Collection}


This research used self-administrated questionnaire for collection by using hand delivery, the population were those customers who travel to and from Pakistan, for sure the population is large, a convenience sampling is used, as sampling was done by distributing questionnaire to customer/passenger at two different airport of capital city called Islamabad in Pakistan and size of sample was 200 respondent which represent the total number of questionnaire that distributed to customer, a screening question during survey was asked from passenger, whether these respondents involve in service recovery situation.

\section{Analysis and Results}

Descriptive Statistics

First of all, this paper analyzes the frequency and percentage of the basic information about the gender, age, occupation, education qualification (See Table 1.1).

This paper uses the indicators in table 1.3 below for descriptive statistical analysis in the formal questionnaires. The variable shown below are Service Recovery (SR),
Table 1.1 Distribution of Basic Characteristics -.The Final Sample

\begin{tabular}{|c|c|c|c|}
\hline Demographics & Category & Frequency & $\begin{array}{l}\text { Percent } \\
(\%)\end{array}$ \\
\hline \multirow[t]{2}{*}{ Gender } & Male & 158 & 79 \\
\hline & Female & 42 & 21 \\
\hline \multirow[t]{4}{*}{ Age } & $\begin{array}{l}20 \& \\
\text { below }\end{array}$ & 16 & 8 \\
\hline & $20-25$ & 64 & 32 \\
\hline & $25-30$ & 92 & 46 \\
\hline & $\begin{array}{l}30 \& \\
\text { above }\end{array}$ & 28 & 14 \\
\hline \multirow[t]{4}{*}{ Occupation } & Student & 157 & 78.5 \\
\hline & Employee & 29 & 14.5 \\
\hline & Business & 11 & 5.5 \\
\hline & $\begin{array}{l}\text { Owner } \\
\text { Other }\end{array}$ & 3 & 1.5 \\
\hline \multirow{5}{*}{$\begin{array}{l}\text { Education } \\
\text { qualification }\end{array}$} & High & & \\
\hline & School \& & 5 & 2.5 \\
\hline & below & 4 & 2 \\
\hline & College & 186 & 93 \\
\hline & $\begin{array}{l}\text { University } \\
\text { Other }\end{array}$ & 5 & 2.5 \\
\hline
\end{tabular}

Customer Emotion (CE), Perceived Fairness (PF), and Repurchase Intentions (RI). The specific analysis results are in Table 1.3.

Table 1.2 Descriptive Statistics

\begin{tabular}{llllllllll}
\hline Variables & $\mathrm{N}$ & Minimum & Maximum & Mean & $\begin{array}{l}\text { Std. } \\
\text { Deviation }\end{array}$ & \multicolumn{2}{l}{ Skewness } & \multicolumn{2}{l}{ Kurtosis } \\
\hline $\mathrm{SR}$ & 200 & 1.00 & 4.42 & 2.6921 & .79673 & -.085 & .172 & -.591 & .342 \\
$\mathrm{CE}$ & 200 & 1.00 & 5.00 & 3.0120 & .55701 & .096 & .172 & 1.705 & .342 \\
$\mathrm{PF}$ & 200 & 1.76 & 4.90 & 3.0913 & .59059 & .196 & .172 & -.041 & .342 \\
$\mathrm{RI}$ & 200 & 1.00 & 5.00 & 2.9075 & 1.09599 & -.137 & .172 & -.585 & .342 \\
\hline
\end{tabular}

All scales in this paper use the 5-point Likert scale. Above

Table 5.2 we can see, the minimum, maximum values of each variable are concentrated 1 to 5 . The mean represents the average level of each variable. Also from Table 6, the overall mean value of the Repurchase intention is 2.92 . Service recovery have overall mean value 2.69 , mediator variable perceived fairness have mean value of 3.09 , moderator customer emotions have value of 3.01. The skweness and kurtosis can also be seen.

\section{Reliability}

To ensure the reliability of the subsequent results, there need to conduct the reliability on the data of the formal investigation. Based on 200 valid questionnaire data, this paper used SPSS v.21.0 for the reliability test of variables. See Table 1.4

Results can be seen at table 1.4 above that the Cronbach's

\begin{tabular}{lll}
\hline Scale Variables & $\begin{array}{l}\text { Cornbach } \\
\text { alpha }\end{array}$ & $\begin{array}{l}\text { Number } \\
\text { of Items }\end{array}$ \\
\hline Service recovery & $\alpha=0.895$ & 12 \\
$\begin{array}{c}\text { Customer Emotions } \\
\text { Positive Customer }\end{array}$ & $\alpha=0.884$ & 3 \\
$\begin{array}{c}\text { Emotions (CEP) } \\
\text { Negative Customer }\end{array}$ & $\alpha=0.748$ & 3 \\
$\begin{array}{l}\text { Emotions (CEN) } \\
\text { Perceived fairness }\end{array}$ & $\alpha=.0 .899$ & 21 \\
$\begin{array}{l}\text { Repurchase intentions } \\
\text { Overall }\end{array}$ & $\alpha=.0 .906$ & 2 \\
\hline
\end{tabular}

alpha coefficients of variables and its dimensions are more than the standard of 0.7 , which signifying that the reliability of each scale is good.

\section{Correlation Analysis}

In this study, a Pearson's correlation coefficients matrix 
among variables was run in SPSS v.21. The analysis

results show that the data can fulfil the basic criteria or

Table 1.4 Correlation Analysis

\begin{tabular}{|c|c|c|c|c|c|c|c|c|c|}
\hline Variables & 1 & 2 & 3 & 4 & 5 & 6 & 7 & 8 & 9 \\
\hline 1.RI & 1 & & & & & & & & \\
\hline 2.SR & $.698^{* *}$ & 1 & & & & . & & & \\
\hline 3.PF & $.628^{* *}$ & $.743^{* *}$ & 1 & & & & & & \\
\hline 4.CEP & $.654^{* *}$ & $.840^{* *}$ & $.759^{* *}$ & 1 & & & & & \\
\hline 5.CEN & $-.205^{* *}$ & $-.275^{* *}$ & $-.159^{*}$ & $-.313^{* *}$ & 1 & & & & \\
\hline 6.Gender & .016 & $.161^{*}$ & .058 & .089 & $-.261^{* *}$ & 1 & & & \\
\hline 7.Age & -.021 & -.047 & -.076 & -.049 & $.169^{*}$ & -.026 & 1 & & \\
\hline 8.Occupation & -.025 & -.060 & -.132 & -.063 & -.013 & $.219^{* *}$ & $.358^{* *}$ & 1 & \\
\hline 9.Education Qualification & .069 & -.003 & .029 & .097 & .062 & -.004 & $.177^{*}$ & -.027 & 1 \\
\hline
\end{tabular}

Perceived Fairness

Above results shows a significant correlation between variables, when looking at the repurchase intentions (RI) and service recovery (SR) the correlation is 0.698 which showing slightly strong relationship. Similarly perceived fairness (PF) have 0.628 which means positive relationship with R. However, with positive customer emotions the relationship is slightly strong at 0.654 whereas negative customer emotions -0.205 shows negative relationship with repurchase intentions.

\section{Hypothesis Testing of Direct Effects}

This study used simple mediation to test the hypotheses of casual influence from service recovery on repurchase intentions paths, one through the proposed mediator perceived fairness (PF) and a second independent of the X- M - Y mechanism. In order to compute the direct and indirect effect, we used Model number 4 by Hayes (2013 in the PROCESS macro on SPSS. See (Fig1.1)

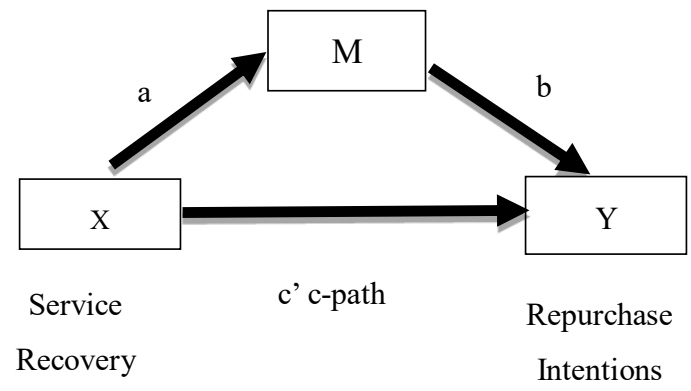

Figure 1.1 Direct and Indirect Effect through Perceived Fairness

\section{Mediation Analysis}

Regression was run to evaluate each element of the mediation model proposed above. These results in table 1.5 and 1.6 shows influence of SR on RI (c-path), the effect of SR on PF (a-path) and the effect of service recovery on repurchase intentions, through perceived fairness (c'-path). At First, table 1.5 shows that SR have significant effect on RI $(\beta=.9606, t=3.1682, p=.0018)$. It can be concluded from this analysis that hypothesis 1 is confirmed. (See table 1.5)

Table 1.5 Total Effect Model

\begin{tabular}{|c|c|c|c|c|c|c|}
\hline \multicolumn{7}{|c|}{ Repurchase Intentions (RI) } \\
\hline \multirow{2}{*}{\multicolumn{2}{|c|}{ Service Recovery (SR) (c-path) }} & \multirow{2}{*}{$\begin{array}{c}\boldsymbol{\beta} \\
.9606^{* * *}\end{array}$} & \multirow{2}{*}{$\begin{array}{c}\text { SE } \\
.0700\end{array}$} & \multirow{2}{*}{$\begin{array}{c}\mathbf{t} \\
13.7275\end{array}$} & \multirow{3}{*}{$\begin{array}{c}\mathbf{p} \\
.0000\end{array}$} & \\
\hline & & & & & & \\
\hline Gender & -.3012 & .1422 & 2.1181 & .0354 & & \\
\hline Age & -.0306 & .0746 & -.4107 & .6818 & & \\
\hline Occupation & .0909 & .0962 & .9452 & .3457 & & \\
\hline \multirow[t]{3}{*}{ Education Qualification } & .2194 & .1492 & 1.4700 & .1432 & & \\
\hline & $\mathbf{R}^{2}$ & MSE & $\mathbf{F}$ & df1 & df2 & $\mathbf{p}$ \\
\hline & .5045 & .6105 & 39.5114 & 5.0000 & 194.0000 & .0000 \\
\hline
\end{tabular}

$* * * \mathrm{P}$ value sig at the .0000 level 
It was also found from the results that service recovery was effect significantly on perceived fairness $(\beta=0.5525$, $\mathrm{t}=15.41, \mathrm{p}=0.000)$, which can be seen in table 5.6.
Lastly, results showed that mediator (perceived fairness) was significantly influence repurchase intentions $(\beta$ $=.4391, \mathrm{t}=3.212, \mathrm{p}=.0018)$. For results (See table. 5.6$)$

Table 1.6 Mediation Analysis: Mediator Variable Model

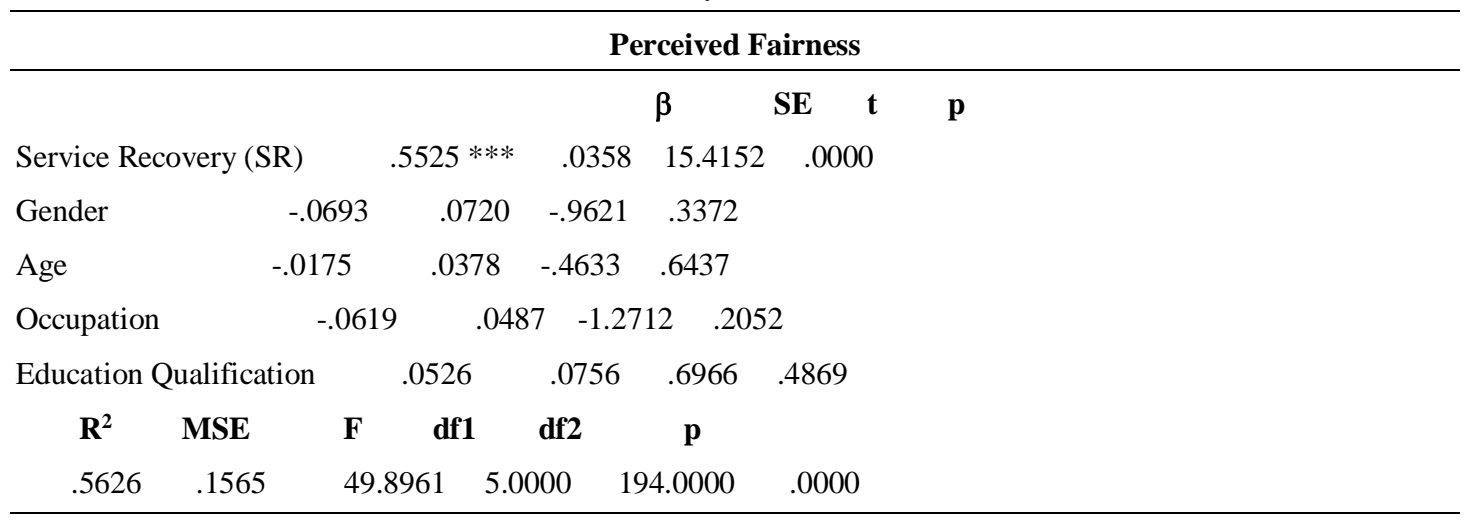

${ }^{* * *} \mathrm{P}$ value sig at the .0000 level

The results in Table 5.7 of the c'-path shows that the influence of SR on RI remained significant, value of coefficient changed $(\beta=.7461, \mathrm{t}=7.2288, \mathrm{p}=.0000)$ when intervening for perceived fairness, thus suggesting mediation. Therefore, according to mediation results we can confirmed that the hypothesis 2 of this study supported well. See (Table 1.7)

Table 1.7 Mediation Analysis: Dependent Variable Model

\begin{tabular}{lcccccc}
\hline \multicolumn{7}{c}{ Repurchase Intention (RI) } \\
\hline & \multicolumn{7}{c}{$\boldsymbol{\beta}$} & SE & $\mathbf{t}$ & $\mathbf{p}$ \\
Service Recovery (SR) & & $.7461^{* * *}$ & .1032 & 7.2288 & .0000 \\
Perceived Fairness (PF) & & $.4391^{* *}$ & .1386 & 3.1682 & .0018 \\
& & & & & \\
Gender & -.2708 & .1393 & -1.9434 & .0534 \\
Age & -.0230 & .0730 & -.3146 & .7534 \\
Occupation & .1181 & .0944 & 1.2509 & .2125 \\
Education qualification & .1963 & .1461 & 1.3437 & .1806 \\
\end{tabular}

$\begin{array}{cccclc}\mathbf{R}^{2} & \text { MSE } & \mathbf{F} & \mathbf{d f 1} & \mathbf{d f 2} & \mathbf{p} \\ .5290 & .5833 & 36.133 & 6.0000 & 193.0000 & .0000\end{array}$

Mediation was further tested using the Hayes (2013) bootstrap samples by (Hayes, 2013). As table 1.8 shows method. In this study, the confidence interval of $95 \%$ in the direct effect of SR $(\mathrm{X})$ on RI $(\mathrm{Y})$ is significant the direct and indirect effects was attained with the 5,000 $(0.7461)(p=.0000)$. For direct effect (See table1.8)

Table 1.8 Direct effect of SR on RI

\begin{tabular}{llllllll}
\hline \multicolumn{10}{c}{ Direct effect of $X$ on $Y$} \\
\hline Effect & $\mathbf{S E}$ & $\mathbf{t}$ & $\mathbf{p}$ & LLCI & ULCI \\
.7461 & .1032 & 7.2288 & .0000 & .5425 & .9497 \\
\hline
\end{tabular}

The effect size reduced to $(0.2426)$ when controlling for perceived fairness, with no p-value and there is no zero fall between upper and lower limits at $95 \%$ confidence interval thus mediation exists. This means that the mediation results support the mediating role of perceived fairness in between (SR) and (RI) which confirmed the hypothesis 2. (See: Table. 1.9 
Table 1.9 Indirect Effect of SR on RI

\begin{tabular}{lcccc}
\hline \multicolumn{5}{c}{ Indirect effect(s) of X on Y } \\
\hline & Effect & BootSE & BootLLCI & BootULCI \\
Perceived Fairness (PF) & .2426 & .0927 & .0735 & .4313 \\
\hline
\end{tabular}

Results found a significant indirect effect of (SR) on (RI) through $\mathrm{PF}, \mathrm{ab}=0.248$, BCa CI [0.77, 0.4319]. The figure below shows a statistical model for mediation of perceived fairness, (See: Fig 1.2)

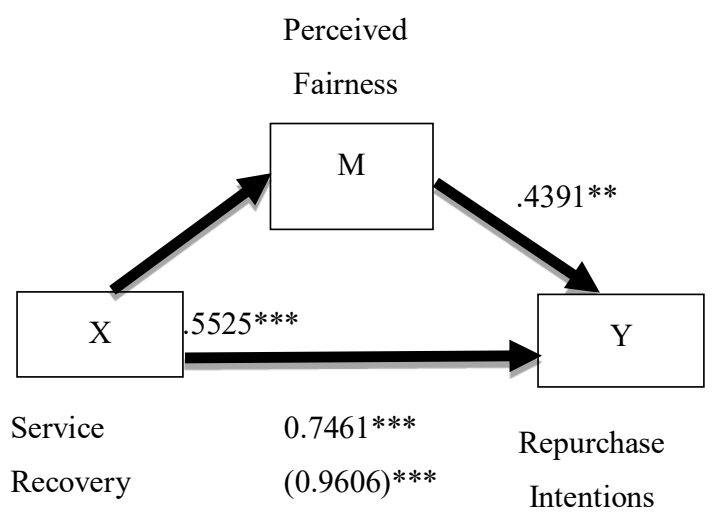

\section{Moderation Analysis}

Simple moderation analysis used for testing hypotheses of casual path of the influence from service recovery on perceived fairness, through the proposed moderator customer emotions. To analyze simple moderation, a model \# 7 of PROCESS macro developed by Hayes (2013) was used. Figure below shows moderation of customer emotions (See: Fig 5.3)
Customer Emotions

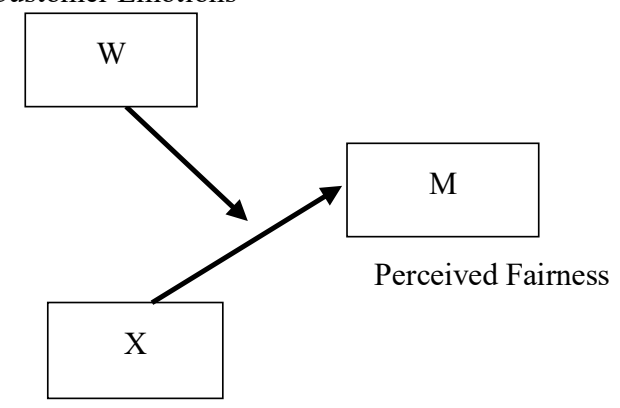

Service Recovery

Figure 1.3 Simple Moderation Model

For testing the moderation of customer emotions, multiple regression was conducted for each component of the moderation model. The results shown in below tables 1.10 and figure 1.11. These results comprises of the relationship between SR and PF (a-path) and interaction effect of SR and customer emotions on perceived fairness. This model demonstrates the part one of the moderated mediation effect.

(1) Positive Customer Emotions

First, the table 1.6 illustrate results that service recovery has significant involvement in perceived fairness $(\beta$ $=.0890, \mathrm{p}=0.3947)$. The interaction effect of service recovery and positive customers emotions (CEP) on perceived fairness has also significant involvement ( $\beta$ $=.1207, \mathrm{p}=.1693$ ). For results (See Table 1.10 and 1.11)

Table 1.10 Moderation of Positive Customer Emotions (CEP)

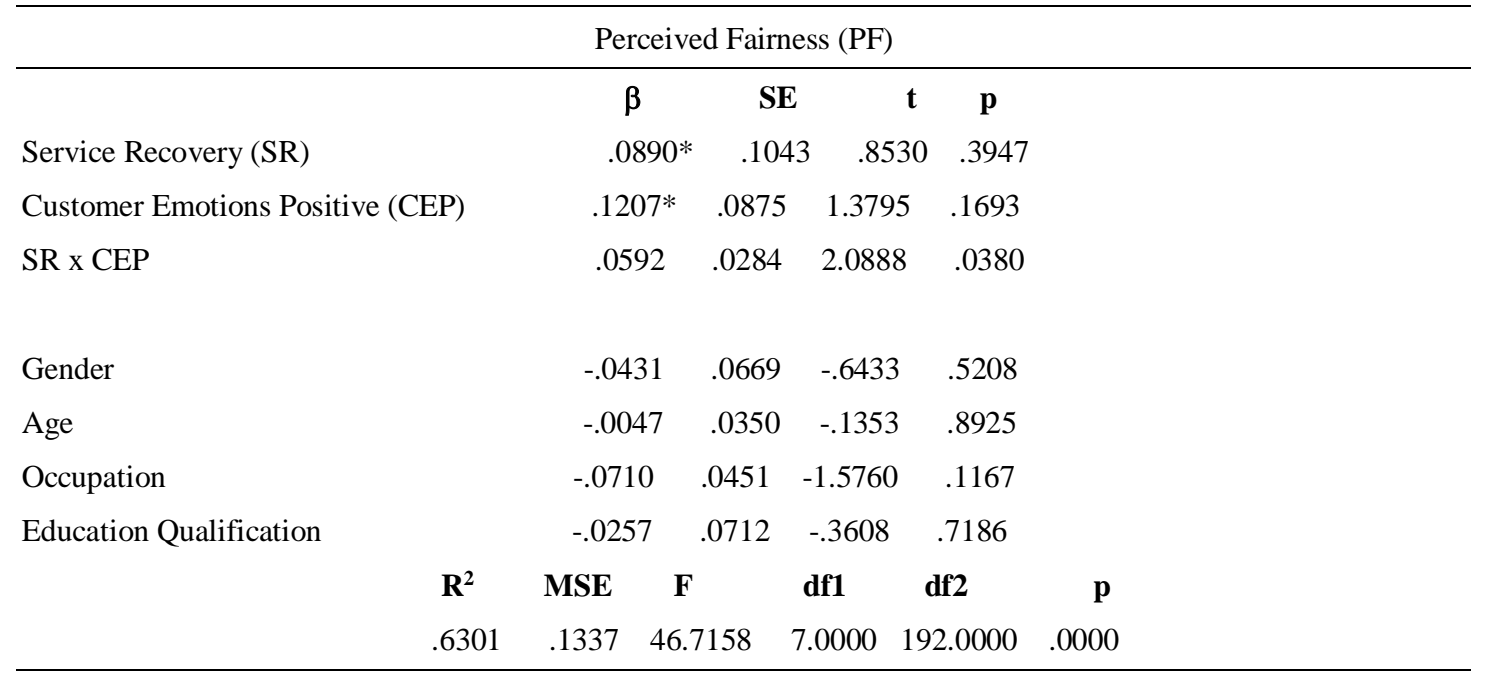

*p value sig at the 0.05 level 
Table 1.11 Conditional effects moderator(s) at different level

\begin{tabular}{lcccccccc}
\hline CEP & effect & se & t & p & \multicolumn{2}{c}{ LLCI } & \multicolumn{2}{c}{ ULCI } \\
\hline 2.0000 & .2074 & .0674 & 3.0755 & .0024 & .0744 & .3405 \\
3.0000 & .2667 & .0616 & 4.3262 & .0000 & .1451 & .3883 \\
& & & & & \\
4.0000 & .3259 & .0683 & 4.7748 & .0000 & .1913 & .4606 \\
\hline
\end{tabular}

Note: 5,000 bootstrap sample

(2) Negative Customer Emotions

The results in table 1.12 shows that SR has significant involvement in perceived fairness $(\beta=0.3348, p$

$=.0013)$. The interaction effect of service recovery and negative customer's emotions (CEP) on perceived

fairness has also significant involvement $(\beta=-0.1738$, $\mathrm{p}=.0590)$. For moderation of CEN and conditional effects (See table 5.12, 5.13)

Table1.12 Moderation of Negative Customer Emotions (CEN)

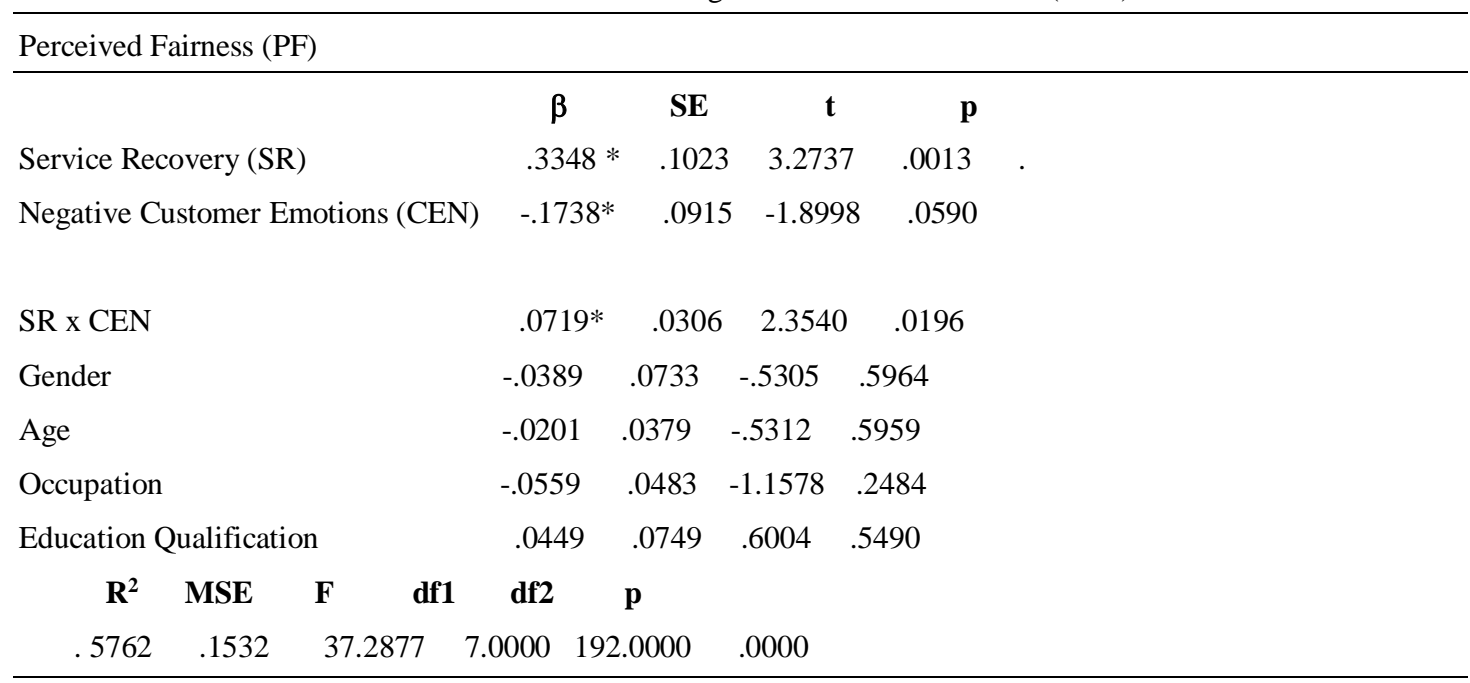

*p value sig at the 0.05 level

Table 1.13 Conditional effects of predictor at moderator(s) values

\begin{tabular}{lrrrrrrr}
\hline & CEN & Effect & SE & $\mathrm{t}$ & $\mathrm{p}$ & LLCI & ULCI \\
\hline Low & 2.0000 & .4786 & .0502 & 9.5348 & .0000 & .3796 & .5776 \\
Moderate & 3.0000 & .5505 & .0368 & 14.9749 & .0000 & .4780 & .6231 \\
High & 4.0000 & .6225 & .0453 & 13.7459 & .0000 & .5331 & .7118 \\
\hline
\end{tabular}

Note: 5,000 bootstrap samples

\section{Moderated Mediation Analysis}

During mediation analysis, we found a significant relationship between SR and RI through perceived fairness. Hypothesis 4 predicted that inferences of perceived fairness moderated by customer emotions, would mediate the relationship between SR and RI. For this hypothesis, the PROCESS macro was by (Hayes, 2013) was run again. To test influence of service recovery and repurchase intentions through perceived fairness, moderated by customer emotions in more detail, the model is using 5,000 bootstrap samples at $95 \%$ confidence for the indirect effect. For moderated mediation model (See Fig 1.4).

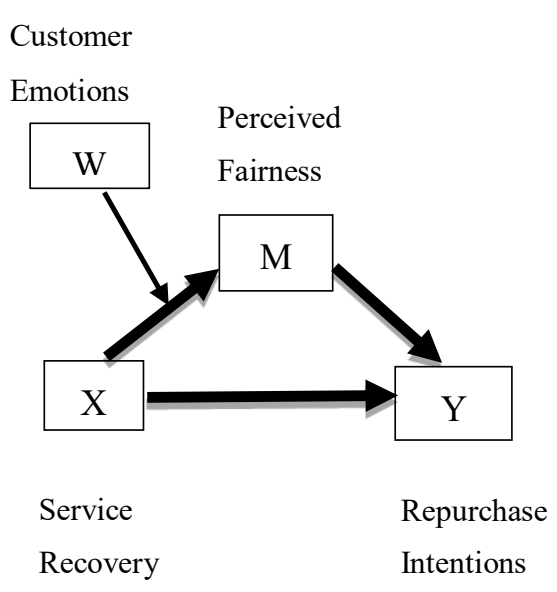


(1) Positive Customer Emotions

While testing indirect effect it we found that there is zero fall in between upper and lower limits of confidence interval which indicates a significant indirect effect at low levels of customer emotions (95\%
Conf. Interval: .0140 to .2108 , moderate levels of customer emotions (95\% Conf. Interval: .0316 to .2378 ), and high levels ( $95 \%$ Conf. Interval: .0420 to .2777) For indirect effects of CEP see Table 1.14.

Table 1.14 Indirect Effect of CEP

Indirect Effect

\begin{tabular}{llcccccc}
\multicolumn{1}{c}{$\mathrm{SR}$} & $\rightarrow$ & $\mathrm{PF}$ & $\rightarrow$ & $\mathrm{RI}$ \\
\hline CEP & Effect & BootSE & BootLLCI & BootULCI \\
Low & 2.0000 & .0911 & .0511 & .0140 & .2108 \\
Moderate & 3.0000 & .1171 & .0528 & .0316 & .2378 \\
High & 4.0000 & .1431 & .0605 & .0420 & .2777 \\
\hline
\end{tabular}

Note: 5,000 bootstrap samples

However, moderated mediation index in then end confidence interval. (See Table 5.15). shows zero between upper and lower limit of

Table 1.15 Index of Moderated Mediation

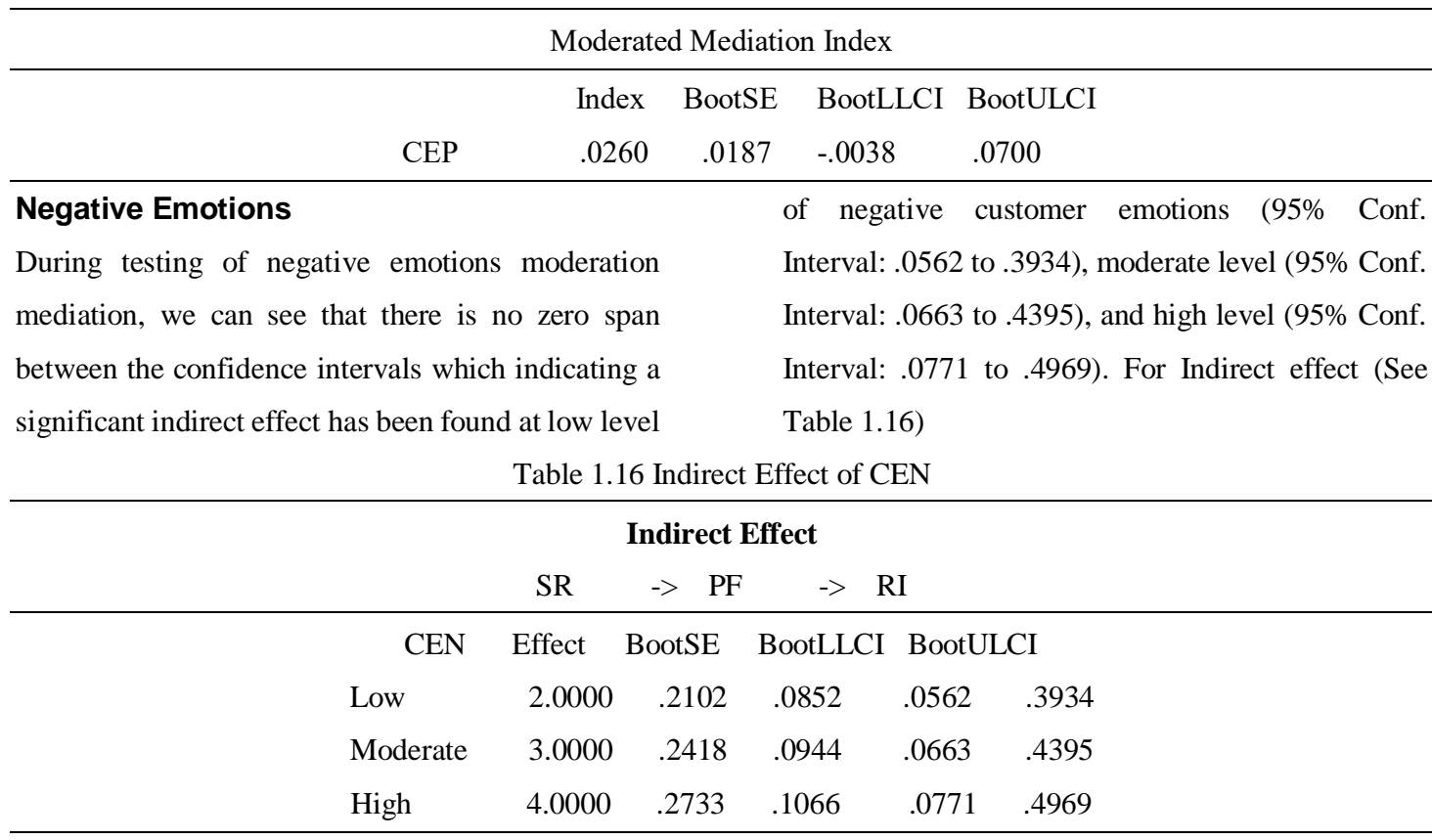

Note: 5,000 bootstrap samples

As we can see that zero is not falling in the confidence intervals, it shows clear evidence that the association between service recovery and repurchase intentions through perceived fairness significantly increase when customer emotions is positive. Consequently, hypothesis 4 is supported. (See Table 1.17)

Table 1.17 Moderated Mediation Index

\begin{tabular}{lcccc}
\hline \multicolumn{7}{c}{ Moderated Mediation Index } \\
\hline & Index & BootSE & BootLLCI & BootULCI \\
CEN & .0316 & .0198 & .0016 & .0766 \\
\hline
\end{tabular}




\section{Discussion}

\section{Managerial Implications}

The hypothetical part of the direct, mediating, moderating, and moderated mediation roles proposed in this paper has been verified, which has made organizations have a clearer understanding of the importance of repurchase during service recovery situation. Empirical evidence support service recovery to be an important determinant in influencing repurchase intention. The management and staff should focus on implications from the study summarized as follows:

Pay closer attention to the recovery response: It can been seen in this study that SR has significant impact on RI, managers of service firm such as airlines firm should focus on effective recovery response in order to increase repurchases, these includes apology, response speed, compensation facilitation effort and solving of problem from organization in after service failure.

Pay attention to the implementation of efforts of recovery backed by the fairness dimensions in service. Firms should emphasis on the efforts and strategies that need to make to hold an exceptional reputation in the minds of service customer during recovery situations, for the purpose to increase repurchases of the company Management and staff should also understand the customer emotions and should be aware from justice perceived by customer in service recovery. This can relief companies avoid negative emotions of customers and also help organization to resolve complaints effectively during adverse situation to increase positive repurchase behavior towards the company which in results leads to higher profits. In the longer term, the airlines management should pay attention on the factors which found in this study. They can continuously improve the actions that includes in SR, to meeting the customer's expectation of fairness through the evaluation with the service they provides.

\section{Research Conclusion}

After methodically combining relevant theories and literatures, this research explores the mediation of perceived fairness and moderation of customer emotions. This study uses Likert scale to form prequestionnaire and all the items were derived from different studies conducted in past, all these studies deal with issues in service recovery, customer emotions, customer perception of fairness/justice, and repurchase as an outcome. By testing the reliability it is found that the repurchase intention, service recovery, perceived fairness and customer emotions scale is good. It is basically consistent with the results of preceding scholars, indicating that these four scales have crosscultural consistency and can be applied to research in the Pakistan context.

Correlation analysis was conducted for the relationship between variables and the results indicates that there is a significant correlation among variables. Firms actions related to compensation, apology and speed during recovery is useful for service provider and a thorough review of literature highlights that these three dimensions are an effective responses from service firms. An apology by firms shows a sense of responsibility for any inconvenience that customer face, while speed in response to customer complaint increase satisfaction and rebuying intentions, similarly compensation in different forms such as discounts, refunds and coupons, enhances repurchase intentions, this can lead to repurchase intention in addition, create positive word of mouth which is highly beneficial for the firms.

Perceived fairness plays a mediate role in this study. Researcher tried to develop the relationship among three dimension of fairness/justice, satisfaction and customer behavioral intentions ${ }^{[33]}$. According to theory of justice, fairness and its dimensions (distributive, interactional, procedural justice) constitute a mediate stage in the process of rendering effort regarding to service recovery which strongly influence customer perception of the ultimate outcome such as repurchase intentions. Therefore, we can conclude that customer future buying intentions depends on customers feelings of whether they were fairly treated and that justice was done or not.

The findings of this study shows that customer emotions moderate the relationship between SR and PF. Sentiments that have high positive or negative valence such as anger/ excitement shows the outcome of service recovery and decides the fairness parameters. For 
instance, during service recovery if he/she face inadequate response he become unhappy or disappointment and if he feels the recovery from provider is suitable, he felt pleasant and happier, these emotions decides the fairness of treatment provided by the firm, therefore we can conclude emotions plays a moderate role.

The findings of this study also reveals that customer emotions moderate the mediation of perceived fairness between SR and RI. The emotions during that process decide the fairness level which then leads to repurchases of services. In applying fairness to recovery event, customer can imagine a number of sequenced actions, when a recovery of service attains positive result than customer will be like to remain more loyal with the service provider, however arising of negative emotions during service recovery felt them to be unfairly treated resulting disloyalty of customer or may unsubscribed from the service.

\section{Limitations and Future Scope}

Every study have their own limitations and this research also have no exception. Researching into four key components of the research (service recovery, perceived fairness, emotions and repurchase intentions) all are having casual effect in past and can be still ascertained, this study is a first of its kind that conducted in the context of airlines companies in Pakistan. Therefore it is consider as an exploratory study by nature and the findings of current study are not easy to compare, because the study that comparable directly, do not exist. Furthermore, this research only used quantitative methods for collection of the data (i.e. survey). Consequently, in future, studies should include other methods of qualitative research such as interviews, with technique called critical incident technique (CIT). The method of CIT have been used by different research in the service failure and recovery research earlier $[83,84,85]$.

Another limitation of our research related to its size and type of sample, as the occurrence of failure in services is uncommon or customer who face recovery situation is not normal. As such, it is not easy to identify an ample amount of airline service failures when taking a random sample form the population. This study was also limited to international passenger while passengers traveling domestically have different opinions on recovery of service. Hence, an empirical investigation or study needed in order to evaluate how domestic customer views are different from that of international customers. Perhaps work in future on more representative and diverse sample would provide fascinating conclusions. More studies should be examine and accomplished in a different situations as well as different countries in order to allow cross-sectional comparison in industry among various customer groups. These kind of research efforts would aid our insights in designing of a suitable service recovery, resulting positive perceptions of fairness, hence increase in customer repurchase.

Finally, apart from the limitations, this study was composed of important contributions in airline industry. We had prolonged the work theoretically, derived definite hypothesis which based on reliable study sample and tested these hypothesis empirically. All of the study hypotheses were supported well and had broad theoretical and managerial implication, therefore, it may inspire/encourage more researches to do research in the area of this study.

\section{References}

[1] Kotler P. Marketing for hospitality and tourism [M] India: Pearson Education, 2003.

[2] Reichheld F.F, Sasser W.E., Zero defection quality comes to services [J]. Harvard Business Review, 1990, 68(5):105-111.

[3] Morwitz V G, Steckel J.H, Gupta A. When do purchase intentions predict sales? [J]. International Journal of Forecasting, 2007, 23(3):347-364.

[4] Lee J. The Effectiveness of Service Recovery on Repurchase Intention: Moderating Effect of Customer Loyalty and Negative Emotion [J]. Academy of Marketing Science (AMS) Annual Conference, 2015. [5] Zeithaml V.A, Berry L.L, Parasuraman A. The behavioral consequences of service quality [J]. Journal of marketing, 1996, 60(2):31-46

[6] Lacey R, Morgan R.M, Customer advocacy and the impact of B2B loyalty programs [J]. Journal of business \& industrial marketing, 2008, 24(1):3-13. 
The Impact of Service Recovery on Repurchase Intentions: A Moderated Mediation Model

Muhammad Salman Latif, Zhang Lanxia., PhD

[7] Spreng R.A, Harrell G.D, Mackoy R.D. Service recovery: impact on satisfaction and intentions $[\mathrm{J}]$. Journal of services marketing, 1995, 9(10:15-23.

[8] Swan J.E, Oliver R L, Postpurchase communications by consumers [J]. Journal of retailing, 1989, 65(4):516.

[9] Bao L, The Effect of Service Recovery on Repurchase Intention in Online Context: The Moderation of Perceived Justice and Psychological Contract $[\mathrm{J}]$. Proceedings of the International Conference on Business and Information Management, 2017.

[10] Jones T, Taylor S F, The conceptual domain of service loyalty: how many dimensions? [J]. Journal of services marketing, 2007, 21(1): 36-51.

[11] Saleem M A, Zahra S, Yaseen A, Impact of service quality and trust on repurchase intentions-the case of Pakistan airline industry [J]. Asia Pacific Journal of Marketing and Logistics, 2017, 29(5):1136-1159.

[12] Ali I, Gilal R G, Shah N, Impact of service recovery on repurchase intentions among customers of cellular industry of pakistan [J]. Grassroots, 2018, 51(2).

[13] Peyrot M, Doren D V, Effect of a class action suit on consumer repurchase intentions [J]. Journal of Consumer Affairs, 1994, 28(2):361-379.

[14] Zineldin M, The royalty of loyalty: CRM, quality and retention $[\mathrm{J}]$. Journal of consumer marketing, 2006, 23(7):430-437.

[15] Hume M, Mort G S, Winzar H, Exploring repurchase intention in a performing arts context: who comes? and why do they come back? [J]. International Journal of Nonprofit and Voluntary Sector Marketing, 2007, 12(2):135-148.

[17] Lapierre J, Customer-perceived value in industrial contexts [J]. Journal of business \& industrial marketing, 2000, 15(2/3):122-145

[18] Oliver R L, Cognitive, affective, and attribute bases of the satisfaction response $[\mathrm{J}]$. Journal of consumer research, 1993, 20(3):418-430.

[19] Luo H, Yu, Impact of service recovery quality on consumers' repurchase intention: The moderating effect of customer relationship quality [J]. International
Conference on Service Systems and Service Management, 2017.

[20] Johnston R, Service failure and recovery: impact, attributes and process $[\mathrm{J}]$. Advances in Services Marketing and Management: Research and Practice, 1995, 4(1):211-228

[21] Bell C, Zemke R, Bush J, Managing knock your socks off service [J] Amacom, 2013.

[22] Seawright K K, et al, An empirical examination of service recovery design $[\mathrm{J}]$. Marketing Intelligence \& Planning, 2008, 26(3):253-274.

[23] Mattila A S, Do women like options more than men? An examination in the context of service recovery [J]. Journal of Services Marketing, 2010, 24(7):499508.

[24] Psomas E L, Bouranta N, Vouzas F, The Effect of Service Recovery on Buying Intention-The role of perceived food safety [J]. International Journal of Quality and Service Sciences, 2017, 11.1: 69-86

[25] Grönroos C, Marketing, management and services [J]. MARQUES, Arlete S.(Trad.). Rio de Janeiro: Elsevier, 2003

[26] Kelley S W, Hoffman K D, Davis M A, A typology of retail failures and recoveries [J]. Journal of retailing, 1993, 69(4):429-452.

[27] Smith A K, Bolton R N, Wagner.J, A.model.of.customer.satisfaction.with.service encounters.involving.failure.and.recovery $[\mathrm{J}]$. Journal.of.marketing.research, 1999,.36(3):356-372.

[28] Weun S, Beatty S E, Jones M A, The impact of service failure severity on service recovery evaluations and post-recovery relationships [J]. Journal of Services Marketing, 2004, 18(2):133-146.

[29] Bell C R, Zemke R E, Service breakdown: the road to recovery [J]. Management review, 1987, 76(10):32.

[31] Karatepe O M, Ekiz E H, The effects of organizational responses to complaints on satisfaction and loyalty: a study of hotel guests in Northern Cyprus [J]. Managing Service Quality: An International Journal, 2004, 14(6):476-486.

[32] Lewis B R, McCann P, Service failure and recovery: evidence from the hotel industry $[\mathrm{J}]$. International Journal of Contemporary Hospitality Management, 2004, 16(1):6-17. 
The Impact of Service Recovery on Repurchase Intentions: A Moderated Mediation Model

Muhammad Salman Latif, Zhang Lanxia., PhD

[33] Karatepe O M, Customer complaints and organizational responses: the effects of complainants' perceptions of justice on satisfaction and loyalty [J]. International

Journal.of.Hospitality.Management,.2006,.25(1):69.90..

[34] Johnston R, Linking complaint management to profit $[\mathrm{J}]$. International Journal of Service Industry Management, 2001, 12(1):60-69.

[35] Bonifield C, Cole C A, Better him than me: social comparison theory and service recovery $[\mathrm{J}]$. Journal of the Academy of Marketing Science, 2008, 36(4):565577.

[36] Gilly M C, Post complaint processes: from organizational response to repurchase behavior [J]. Journal of Consumer Affairs, 1987. 21(2):293-213.

[38] Grewal D, Roggeveen. A L, Tsiros.M, The.effect.of.compensation.on.repurchase intentions.in.service.recovery.[J]..Journal.of.retailing, 2008,.84(4):424.-434..

[39] Blodgett J G, Granbois D H, Walters R G, The effects of perceived justice on complainants' negative word-of-mouth behavior and repatronage intentions [J]. Journal of retailing, 1993, 69(4):399-428.

[40] Tedeschi J T, Norman N, The self and social life [M], McGraw-Hill, USA, 1985, 293:322.

[41] Bitner M J, Booms B H, Mohr L A, Critical service encounters: The employee's viewpoint $[\mathrm{J}]$ Journal of marketing, 1994, 58(4):95-106.

[42] Hart O, Is "Bounded Rationality" an Important Element of a Theory of Institutions? [J]. Journal of Institutional and Theoretical Economics, 1990, 146(4):696-702.

[41] Davidow M., The bottom line impact of organizational responses to customer complaints [J] Journal of hospitality \& tourism research, 2000, 24(4):473-490.

[42] Oliver R L, An investigation of the attribute basis of emotion and related affects in consumption: suggestions for a stage-specific satisfaction framework [J]. ACR North American Advances, 1992.

[43] McColl-Kennedy J R., Daus C S, Sparks B A, The role of gender in reactions to service failure and recovery [J]. Journal of Service Research, 2003, 6(1):66-82.

[44] Chuang S C, et al, The effect of service failure types and service recovery on customer satisfaction: a mental accounting perspective [J]. The Service Industries Journal, 2012, 32(2) 257-271.

[46] McCollough, M A, Berry L L, Yadav M S, An empirical investigation of customer satisfaction after service failure and recovery $[\mathrm{J}]$. Journal of service research, 2000, 3(2):121-137.

[47] Tax S.S, Brown S W, Chandrashekaran M, Customer evaluations of service complaint experiences: implications for relationship marketing [J]. Journal of marketing, 1998, 62(2):60-76.

[48] Rawls J, A theory of justice [M]. USA, Belknap Harvard, 2009.

[49] Siu N Y M, Zhang T J F, Yau C Y J, The roles of justice and customer satisfaction in customer retention: A lesson from service recovery [J]. Journal of business ethics, 2013, 114(4):675-686.

[50] Kim T, Jung-Eun Y J, Lee G, Post-recovery customer relationships and customer partnerships in a restaurant setting $[\mathrm{J}]$. International Journal of Contemporary Hospitality Management, 2012, 24(3):381-401

[51] Maxham III J G, Netemeyer R G, Modeling customer perceptions of complaint handling over time: the effects of perceived justice on satisfaction and intent [J], Journal of retailing, 2002, 78(4):239-252.

[52] Karatepe O M, Vatankhah S, The effects of highperformance work practices and job embeddedness on flight attendants' performance outcomes [J]. Journal of Air Transport Management, 2014, 37:27-35.

[53] Nikbin D, Hyun S S, An empirical study of the role of failure severity in service recovery evaluation in the context of the airline industry $[\mathrm{J}]$. Review of Managerial Science, 2015, 9(4):731-749.

[54] Jasso G, Rosenzweig M R, Smith J P, The earnings of US immigrants: World skill prices, skill transferability and selectivity $[\mathrm{J}]$. New York: Rand Corporation, 2002.

[55] Bagozzi R P, Gopinath M, Nyer P U, The role of emotions in marketing [J]. Journal of the academy of marketing science, 1999, 27(2):184. 
[56] Liljander V, Strandvik T, Emotions in service satisfaction [J]. International journal of service industry management, 1997, 8(2):148-169.

[57] Wallin A T, Antecedents to satisfaction with service recovery $[\mathrm{J}]$. European journal of marketing, 2000, 34(1/2):156-175.

[58] Smith A K, Bolton R N, The effect of customers' emotional responses to service failures on their recovery effort evaluations and satisfaction judgments [J]. Journal of the academy of marketing science, 2002, 30(1):5-23.

[59] Lazarus R S, Lazarus R S, Emotion and adaptation [M]. London, Oxford University Press on Demand, 1991.

[60]Beaudry.A,.Pinsonneault.A,.The.other.side.of.acce ptance:.studying.the.direct.andindirect effects of emotion on information technology us [J]. MIS quarterly, 2010: 689 -710.

[61] Loewenstein G F, et al, Risk as feelings. Psychological bulletin [J], 2001, 127(2):267.

[62] Gratch J, Marsella S, A domain-independent framework for modeling emotion. Cognitive Systems Research [J], 2004, 5(4):269-306.

[63] Barsky J, Nash L, Evoking emotion: affective keys to hotel loyalty. Cornell Hotel and Restaurant [J]. Administration Quarterly, 2002, 43(1):39-46.

[64] Rychalski A, Hudson S, Asymmetric effects of customer emotions on satisfaction and loyalty in a utilitarian service context [J]. Journal of Business Research, 2017, 71:84-91.

[65] Ahern G L, Schwartz G E, Differential lateralization for positive and negative emotion in the human brain: EEG spectral analysis [J]. Neuropsychologia, 1985, 23(6):745-755.

[66] Davidson R J, et al., Approach-withdrawal and cerebral asymmetry: emotional expression and brain physiology [J]. I. Journal of personality and social psychology, 1990, 58(2):330.

[67] Watson D, Clark L A, The PANAS-X: Manual for the positive and negative affect schedule-expanded form, 1999.

[69] Lively K J, Heise D R, Emotions in affect control theory. Handbook of the Sociology of Emotions [M]. Springer, 2014, 2:51-75.
[70] Heise D R., Understanding events: Affect and the construction of social action [J]. CUP Archive, 1979.

[71] Homans G C, Social behavior: Its elementary forms $[\mathrm{M}]$, England, Harcourt Brace Jovanovich, Oxford, 1974.

[72] Palmer A, Beggs R, Keown-McMullan C, Equity and repurchase intention following service failure $[\mathrm{J}]$. Journal of Services Marketing, 2000, 14(6): 513-528.

[73] Chebat J C, Slusarczyk W, How emotions mediate the effects of perceived justice on loyalty in service recovery situations: an empirical study [J]. Journal of Business Research, 2005, 58(5): 664-673.

[74] Seiders K, Berry LL, Service fairness: What it is and why it matters [J]. Academy of Management Perspectives, 1998, 12(2):8-20.

[75] Saunders M, Lewis P, Thornhill A, Research methods for business students [J]. Essex. Financial Times/Prentice Hall, 2009:1-2.

[76] Gray D E, Doing research in the real world [M]. London: Sage 2013.

[77]Oppenheim A N, Questionnaire design and attitude measurement [M]. England: Oxford, 1966.

[78] Cooper R, Schindler P S, Business research methods. New York, 2003. 10020

[79] Fowler F J, Survey Research Methods [M]. Thousand Oaks: Sage, 2002.

[80] Hayes A F, Introduction to mediation, moderation, and conditional process analysis: A regression-based approach [M]. New York: Guilford Press, (2013).

[81] Lively K, Heise D, Emotions in Affect Control Theory. In: Stets J., Turner J. (eds) Handbook of the Sociology of Emotions [M], Dordrecht, Springer, 2014. [82] Peng K H, A Study of customer satisfaction and loyalty with service recovery and perceive justice [J]. Management Business Administration, 2007, 2(8): $97-$ 125 .

[83] Bejou D, Palmer A, Service failure and loyalty: an exploratory empirical study of airline customers [J]. Journal of Services Marketing, 1998, 12(1) 